\title{
Evaluation of treatment outcomes for Stenotrophomonas maltophilia bacteraemia
}

\author{
B. Lakatos • B. Jakopp • A. Widmer • \\ R. Frei $\cdot$ H. Pargger $\cdot$ L. Elzi $\cdot$ M. Battegay
}

Received: 23 December 2013/Accepted: 22 February 2014/Published online: 14 March 2014

(c) Springer-Verlag Berlin Heidelberg 2014

\begin{abstract}
Objective The goal of this study was to retrospectively collect data about treatment outcomes in patients diagnosed with Stenotrophomonas maltophilia bacteraemia over a period of 20 years and evaluate these data with respect to the efficacy of treatment options.

Methods The setting was a 700-bed tertiary care hospital in a large urban area. Hospital databases and medical records provided information about episodes of $S$. maltophilia, patient characteristics and treatment outcomes. Patients with at least one positive blood culture for $S$. maltophilia were included in the study. Data were analysed with respect to clinical improvement and mortality $\leq 30$ days after the onset of infection. We compared patient characteristics, laboratory values and treatments by using the Chi-square or Fisher's exact tests and the MannWhitney test.

Results We investigated 27 patients with S. maltophilia bacteraemia. The focus of infection was a central venous
\end{abstract}

B. Lakatos and B. Jakopp contributed equally to this work.

B. Lakatos · B. Jakopp · A. Widmer · L. Elzi ·

M. Battegay $(\square)$

Division of Infectious Diseases and Hospital Epidemiology, University Hospital Basel, Petersgraben 4, 4031 Basel,

Switzerland

e-mail: manuel.battegay@usb.ch

R. Frei

Division of Clinical Microbiology, University Hospital Basel,

Petersgraben 4, 4031 Basel, Switzerland

H. Pargger

Department of Anesthesiology and Intensive Care Medicine,

University Hospital Basel, Petersgraben 4, 4031 Basel,

Switzerland catheter in $18(67 \%)$ cases. The 30-day mortality rate was $11 \%$. All patients who were treated with an antibiotic that was effective in vitro against the pathogen recovered clinically and survived $\geq 30$ days after the onset of infection. The most frequently used antibiotic was trimethoprim-sulfamethoxazole administered alone or in combination with a fluoroquinolone.

Conclusions Despite the fact that S. maltophilia is resistant to multiple antibiotics, the prognosis for patients with $S$. maltophilia bacteraemia is good when they are treated with antibiotics that are effective against this pathogen in vitro.

Keywords Stenotrophomonas maltophilia . Bacteraemia · Antimicrobial therapy · Trimethoprimsulfamethoxazole $\cdot$ Bacteraemia mortality

\section{Introduction}

Stenotrophomonas maltophilia, a Gram-negative, non-fermentative bacillus, is increasingly being recognised as a cause of nosocomial infections [1], but the treatment of a $S$. maltophilia infection is challenging. This is primarily due to the inherent resistance of $S$. maltophilia to multiple classes of antibiotics, including beta-lactams, aminoglycosides and carbapenems [2]. Given the lack of randomised clinical trials to test treatment options for S. maltophilia bacteraemia, current recommendations for treatment are based mostly on in vitro susceptibility tests and expert opinion. Trimethoprim-sulfamethoxazole (TMP/SMX) is the usual drug of choice because of its excellent in vitro activity against $S$. maltophilia. A high dose of TMP $(15 \mathrm{mg} / \mathrm{kg} / \mathrm{day})$ is generally recommended to reduce the risk of emerging resistance to TMP/SMX [1]. However, 
allergic reactions and toxicities related to the administration of TMP/SMX in patients limit the use of this drug in clinical practice [3]. Fluoroquinolones are an alternative option for treatment, if the pathogen is shown to be susceptible to the specific antimicrobial in vitro $[1,2]$. The reported mortality rates of $S$. maltophilia infections are high, i.e. 15-62 \%. However, most studies did not focus on therapeutic aspects [4-7].

The goal of this study was to retrospectively collect information about the treatment of $S$. maltophilia bacteraemia and its outcomes over a period of 20 years in a single-centre setting and to describe the effectiveness of the treatment.

\section{Patients and methods}

The setting for this study was a 700-bed tertiary care hospital that is associated with a university in a large urban area of approximately half a million inhabitants. To retrospectively study outcomes for the treatment of $S$. maltophilia bacteraemia, we chose to review all episodes of S. maltophilia bacteraemia over a 20 -year period beginning in January 1993 and ending in January 2013. Data were collected by first reviewing the microbiology database at the University Hospital Basel to identify episodes of $S$. maltophilia bacteraemia and then by cross-checking this information with data in the databases of the Clinical Microbiology Laboratory and the Infection Control Division at the hospital to identify the specific patient cases associated with these episodes of bacteraemia. All patients who had one or more blood cultures that were positive for S. maltophilia were included in the study. Hospital medical records provided information about patient demographic characteristics, co-morbidities, the focus of the infection attributed to $S$. maltophilia, the number of positive blood cultures, time to positivity of blood cultures, the susceptibility of the identified pathogen in each case to specific antimicrobial agents in vitro, and the type and duration of both empirical and targeted antibiotic therapy. Treatment outcomes were assessed with respect to clinical improvement and 30-day mortality in the patients.

Empirical therapy was defined as the administration of antibiotics at the onset of symptoms of bacteraemia. Adequate treatment was defined as the targeted administration of at least one antimicrobial agent to which S. maltophilia was susceptible in vitro.

Nosocomial infections and sepsis were defined according to the Centers for Disease Control and Prevention (CDC) and international consensus definitions [8]. In brief, a positive blood culture with $S$. maltophilia was defined as 'catheter-related' if a central venous line was in place $\geq 48 \mathrm{~h}$ and $S$. maltophilia was cultured from the catheter tip with more than 15 colony-forming units. We used the term 'catheter-associated' for cases having a central venous catheter for $48 \mathrm{~h}$ or more and without any evidence for another source.

A patient was considered immunosuppressed if they were receiving chemotherapy or radiotherapy for malignancies, immunosuppressive therapies with a daily dose $\geq 10 \mathrm{mg}$ prednisolone-equivalent steroid, monoclonal antibodies, antimetabolite drugs or T cell inhibitors within the preceding 30 days of the positive blood culture. Neutropaenia (absolute neutrophil granulocyte cell count of $<0.5 \times 10^{9} / \mathrm{L}$ ) at the time of bacteraemia was also defined as immunosuppression.

The S. maltophilia isolates from infection episodes that were reported in the microbiology database had been detected in the Clinical Microbiology Laboratory by using standard assays, including API20 NE (bioMérieux, France), VITEK 2 (bioMérieux, France) and MALDI Biotyper (Bruker Daltonik, Germany), or, in special cases, by sequencing of the 16S rRNA gene. For susceptibility testing in vitro, the commercial systems Micronaut (Merlin, Germany), VITEK 2 (bioMérieux, France) or Etest (bioMérieux, France) were used [9]. From 1993 through May 2011, the results for antimicrobial susceptibility were interpreted according to the standards of the Clinical and Laboratory Standards Institute [CLSI, formerly National Committee for Clinical Laboratory Standards (NCCLS)]. From June 2011 onwards, they were interpreted according to the standards of the European Committee on Antimicrobial Susceptibility Testing (EUCAST).

Patient characteristics, laboratory values and treatments were compared by using the Chi-square or Fisher's exact tests for categorical variables and the Mann-Whitney test for continuous variables. Analyses were performed by using SPSS version 21 software (SPSS Inc., USA).

To more definitively characterise treatment outcomes, patients were assigned to one of two groups. The two groups were defined by the adequacy of treatment.

The study was approved by the Ethical Committee of Basel (178/13).

\section{Results}

S. maltophilia was identified in almost 1,000 microbiological samples over the 20-year study period. From these data, we identified 29 patients with at least one positive blood culture for $S$. maltophilia. Two patients were excluded from the study because detailed medical data were not available for them. Table 1 shows the baseline patient characteristics for the two treatment groups to which patients were assigned: the group which received adequate treatment and the group which did not receive 
Table 1 Baseline characteristics of 27 patients diagnosed with Stenotrophomonas maltophilia bacteraemia in a single-centre study over a period of 20 years

\begin{tabular}{|c|c|c|c|}
\hline Variable & $\begin{array}{l}\text { Group } \\
\text { receiving } \\
\text { adequate } \\
\text { treatment }^{\mathrm{a}} \\
(n=21)\end{array}$ & $\begin{array}{l}\text { Group not } \\
\text { receiving } \\
\text { adequate } \\
\text { treatment } \\
(n=6)\end{array}$ & $\begin{array}{l}p \text { - } \\
\text { Value }\end{array}$ \\
\hline $\begin{array}{l}\text { Median age in years } \\
\text { (IQR) }\end{array}$ & $59(43-69)$ & $72(71-77)$ & $<0.001$ \\
\hline Number of males & $9(43 \%)$ & $3(50 \%)$ & 0.756 \\
\hline \multicolumn{4}{|l|}{ Number of patients with: } \\
\hline \multicolumn{4}{|l|}{ Comorbidity } \\
\hline $\begin{array}{l}\text { Cardiovascular } \\
\text { disease }\end{array}$ & $9(43 \%)$ & $4(66 \%)$ & 0.352 \\
\hline Renal impairment ${ }^{\mathrm{b}}$ & $5(24 \%)$ & $3(50 \%)$ & 0.245 \\
\hline Diabetes mellitus & $3(14 \%)$ & $2(33 \%)$ & 0.318 \\
\hline Immunosuppression & $9(43 \%)$ & $3(50 \%)$ & 0.829 \\
\hline Sepsis & $19(90 \%)$ & $5(83 \%)$ & 0.623 \\
\hline $\begin{array}{l}\text { Polymicrobial } \\
\text { infection }\end{array}$ & $8(38 \%)$ & $1(17 \%)$ & 0.617 \\
\hline $\begin{array}{l}\text { Median length (in } \\
\text { days) of hospital stay } \\
\text { prior to onset of } \\
\text { bacteraemia (IQR) }\end{array}$ & $10(6-13)$ & $18(5-38)$ & 0.387 \\
\hline $\begin{array}{l}\text { ICU stay within } \\
30 \text { days }\end{array}$ & $4(19 \%)$ & $5(83 \%)$ & 0.004 \\
\hline $\begin{array}{l}\text { Prior hospitalisation } \\
\text { within } 30 \text { days }\end{array}$ & $8(38 \%)$ & $3(50 \%)$ & 0.662 \\
\hline \multicolumn{4}{|c|}{ Number of patients with a bacteraemia focus that was: } \\
\hline Central line & $15(71 \%)$ & $3(50 \%)$ & 0.326 \\
\hline Pneumonia & $4(29 \%)$ & $3(50 \%)$ & 0.289 \\
\hline Other ${ }^{\mathrm{c}}$ & $2(10 \%)$ & 0 & 1.000 \\
\hline $\begin{array}{l}\text { Median C-reactive } \\
\text { protein in } \mathrm{mg} / \mathrm{l} \text { (IQR) }\end{array}$ & $116(77-229)$ & $121(63-165)$ & 0.887 \\
\hline $\begin{array}{l}\text { Median creatinine in } \\
\mu \mathrm{mol} / \mathrm{l}(\mathrm{IQR})\end{array}$ & $76(58-93)$ & $102(97-108)$ & 0.307 \\
\hline $\begin{array}{l}\text { Median number of } \\
\text { hours between onset } \\
\text { of symptoms and a } \\
\text { positive blood culture } \\
\text { (IQR) }\end{array}$ & $24(22-29)$ & $24(22-24)$ & 0.563 \\
\hline $\begin{array}{l}\text { Number of patients } \\
\text { who died within } \\
30 \text { days after onset of } \\
\text { symptoms of } \\
\text { bacteraemia }\end{array}$ & 0 & $3(50 \%)$ & 0.007 \\
\hline
\end{tabular}

$I Q R$ interquartile range, $I C U$ intensive care unit

a Adequate treatment: defined as the targeted administration of at least one antimicrobial agent to which $S$. maltophilia was susceptible in vitro

b Renal impairment: defined as a creatinine clearance of $<60 \mathrm{ml} / \mathrm{min}$

c Other: urinary tract infection (patient 2), surgical site infection (patient 25) adequate treatment. Table 2 describes in more detail the therapeutic treatment for each patient.

All of the patients had multiple co-morbidities, and 12 (44\%) of them were immunosuppressed. Twenty-five (93\%) patients had been seen by a specialist in the Infectious Diseases Consultant Service. All bacteraemia episodes except for one were nosocomial infections. The most common focus of bacteraemia was a central line, followed by a focus in the respiratory tract (Table 1). Detailed data on central venous catheter insertion and removal could be analysed in 17 of 18 patients. The duration of central venous catheter use was 15 days (median; IQR 12-21) at the diagnosis of S. maltophilia in blood culture. After obtaining blood culture results, catheters were removed within 1 day (median; IQR $0-3$ ). The majority of patients had also been diagnosed with sepsis $(24 ; 89 \%)$, of whom seven had septic shock. Most patients (78\%) had been treated with broad-spectrum antibiotics within the 30 days prior to the onset of S. maltophilia bacteraemia symptoms. The median number of $S$. maltophilia-positive blood cultures was 1 (IQR 1-2), and the median time to positivity was $24 \mathrm{~h}$ in the blood culture system. S. maltophilia was identified as the single pathogen present in cultures for $18(67 \%)$ of the patients. All isolates of S. maltophilia were susceptible to TMP/SMX, 12 isolates $(41 \%)$ were intermediate susceptible or resistant to ciprofloxacin and only one isolate was resistant to levofloxacin from the 17 isolates tested. Six patients were treated with antimicrobial agents that were not active in vitro. In this latter group, patients 15, 24 and 27 (Table 2) died before their treatment was changed as recommended by the specialist in infectious diseases, and patients 5, 11 and 16 (Table 2) survived their bacteraemia episodes. Ventilator-associated pneumonia (VAP) was identified as the source of bacteraemia in two out of three patients (patients 24 and 27) with fatal outcome. For patients 5 and 16 (Table 2), central catheters were removed and no further antibiotic treatment was administered. The positive blood culture of patient 11 (Table 2) was retrospectively considered as a contamination.

Of the 21 patients who were defined as having received adequate treatment, $16(76 \%)$ were treated with TMP/ SMX alone, two were treated with TMP/SMX in combination with fluoroquinolones and three were treated with fluoroquinolones alone. Detailed information about the dosages and side effects of TMP/SMX monotherapy for patients in this study is shown in Table 3.

The 30-day mortality rate of patients with $S$. maltophilia bacteraemia was $11 \%$ (3 of 27 patients). All patients who received treatment with an antibiotic shown to be effective 
Table 2 Focus of infection and type of antibiotic treatment for 27 patients diagnosed with $S$. maltophilia bacteraemia

\begin{tabular}{|c|c|c|c|c|c|c|c|}
\hline Patient & $\begin{array}{l}\text { Age } \\
\text { (years) }\end{array}$ & Gender & $\begin{array}{l}\text { Focus of } S . \text { maltophilia } \\
\text { bacteraemia/associated clinical } \\
\text { condition }\end{array}$ & $\begin{array}{l}\text { Empirical therapy } \\
\text { antimicrobials }\end{array}$ & $\begin{array}{l}\text { Targeted } \\
\text { therapy } \\
\text { antimicrobials }\end{array}$ & $\begin{array}{l}\text { Duration of } \\
\text { targeted therapy } \\
\text { (days) }\end{array}$ & Survived $\geq 30$ days? \\
\hline 1 & 63 & $\mathrm{~F}$ & CLR/metastatic breast cancer & Cefepime & TMP/SMX & 13 & Yes \\
\hline 2 & 66 & M & $\begin{array}{l}\text { Urosepsis/bladder urothelial } \\
\text { carcinoma }\end{array}$ & Ciprofloxacin & TMP/SMX & 18 & Yes \\
\hline 3 & 46 & $\mathrm{~F}$ & CLR/severe cellulitis & $\begin{array}{l}\text { Piperacillin/ } \\
\text { tazobactam }\end{array}$ & TMP/SMX & 14 & Yes \\
\hline 4 & 60 & $\mathrm{~F}$ & $\mathrm{VAP} /$ necrotising fasciitis & $\begin{array}{l}\text { Piperacillin/ } \\
\text { tazobactam }\end{array}$ & TMP/SMX & 14 & Yes \\
\hline 5 & 67 & $\mathrm{~F}$ & CLA/secondary amyloidosis & Imipenem & - & - & Yes \\
\hline 6 & 76 & $\mathrm{~F}$ & $\begin{array}{l}\text { CLA/abdominal injury, } \\
\text { multimorbidity }\end{array}$ & Ciprofloxacin & TMP/SMX & 14 & Yes \\
\hline 7 & 59 & M & $\begin{array}{l}\text { CLA/septic shock with } \\
\text { Staphylococcus aureus }\end{array}$ & $\begin{array}{l}\text { Piperacillin/ } \\
\text { tazobactam }\end{array}$ & TMP/SMX & 4 & Yes \\
\hline 8 & 30 & M & $\begin{array}{l}\text { CLR/intravenous drug use, } \\
\text { community-acquired sepsis }\end{array}$ & $\begin{array}{l}\text { Piperacillin/ } \\
\text { tazobactam }\end{array}$ & Ciprofloxacin & 14 & Yes \\
\hline 9 & 58 & M & CLA/multiple myeloma & TMP/SMX & $\begin{array}{l}\text { TMP/SMX, } \\
\text { ciprofloxacin }\end{array}$ & 17 & Yes \\
\hline 10 & 50 & M & $\begin{array}{l}\text { Pneumonia/severe pulmonary } \\
\text { fibrosis }\end{array}$ & $\begin{array}{l}\text { Piperacillin/ } \\
\text { tazobactam }\end{array}$ & $\begin{array}{l}\text { TMP/SMX, } \\
\text { levofloxacin }\end{array}$ & 17 & Yes \\
\hline 11 & 71 & M & $\begin{array}{l}\text { Pneumonia/bowel ischaemia } \\
\text { and resection/hypovolaemic } \\
\text { shock }\end{array}$ & $\begin{array}{l}\text { Piperacillin/ } \\
\text { tazobactam, } \\
\text { metronidazole }\end{array}$ & - & - & Yes \\
\hline 12 & 15 & $\mathrm{~F}$ & CLR/polytrauma & Cefepime & TMP/SMX & 13 & Yes \\
\hline 13 & 48 & M & CLA/acute myeloid leukaemia & Meropenem & TMP/SMX & 14 & Yes \\
\hline 14 & 69 & M & Pneumonia/prostate cancer & $\begin{array}{l}\text { Piperacillin/ } \\
\text { tazobactam }\end{array}$ & Ciprofloxacin & 14 & Yes \\
\hline 15 & 71 & M & $\begin{array}{l}\text { CLA/metastatic prostate } \\
\text { carcinoma }\end{array}$ & $\begin{array}{l}\text { Amoxicillin/ } \\
\text { clavulanate }\end{array}$ & - & - & No \\
\hline 16 & 72 & M & CLA/hepatic abscess & $\begin{array}{r}\text { Vancomycin, } \\
\text { tobramycin }\end{array}$ & - & - & Yes \\
\hline 17 & 71 & M & $\begin{array}{l}\text { CLA/parkinsonism and severe } \\
\text { pneumonia }\end{array}$ & $\begin{array}{l}\text { Piperacillin/ } \\
\text { tazobactam }\end{array}$ & TMP/SMX & 9 & Yes \\
\hline 18 & 25 & $\mathrm{~F}$ & $\begin{array}{l}\text { CLA/acute lymphoblastic } \\
\text { leukaemia }\end{array}$ & TMP/SMX & TMP/SMX & 14 & Yes \\
\hline 19 & 76 & M & $\begin{array}{l}\text { Pneumonia/urinary tract } \\
\text { infection }\end{array}$ & $\begin{array}{l}\text { Piperacillin/ } \\
\text { tazobactam }\end{array}$ & Ciprofloxacin & 14 & Yes \\
\hline 20 & 71 & $\mathrm{~F}$ & $\begin{array}{l}\text { CLA/complicated hip prosthesis } \\
\text { infection }\end{array}$ & $\begin{array}{r}\text { TMP/SMX, } \\
\text { ertapenem }\end{array}$ & TMP/SMX & 14 & Yes \\
\hline 21 & 80 & $\mathrm{~F}$ & $\begin{array}{l}\text { CLR/Staphylococcus aureus } \\
\text { sepsis }\end{array}$ & $\begin{array}{l}\text { Piperacillin/ } \\
\text { tazobactam }\end{array}$ & TMP/SMX & 15 & Yes \\
\hline 22 & 68 & $\mathrm{~F}$ & CLA/acute myeloid leukaemia & Ciprofloxacin & TMP/SMX & 16 & Yes \\
\hline 23 & 44 & $\mathrm{~F}$ & CLA/HIV, endometrial cancer & $\begin{array}{l}\text { Piperacillin/ } \\
\text { tazobactam }\end{array}$ & TMP/SMX & 20 & Yes \\
\hline 24 & 80 & $\mathrm{~F}$ & $\begin{array}{l}\text { VAP/myocardial infarction and } \\
\text { brain death }\end{array}$ & - & - & - & No \\
\hline 25 & 39 & $\mathrm{~F}$ & $\begin{array}{l}\text { Surgical site infection/distortion } \\
\text { trauma }\end{array}$ & $\begin{array}{l}\text { Piperacillin/ } \\
\text { tazobactam }\end{array}$ & TMP/SMX & 14 & Yes \\
\hline 26 & 35 & $\mathrm{~F}$ & $\begin{array}{l}\text { CLA/complications from } \\
\text { Caesarean section }\end{array}$ & $\begin{array}{l}\text { Amoxicillin/ } \\
\text { clavulanate }\end{array}$ & TMP/SMX & 14 & Yes \\
\hline 27 & 78 & $\mathrm{~F}$ & VAP/chronic heart failure & $\begin{array}{l}\text { Piperacillin/ } \\
\text { tazobactam }\end{array}$ & - & - & No \\
\hline
\end{tabular}

$F$ female, $M$ male, TMP/SMX trimethoprim-sulfamethoxazole, $C L R$ central line-related, $C L A$ central line-associated, VAP ventilator-associated pneumonia, $H I V$ human immunodeficiency virus 
Table 3 Details about TMP/SMX monotherapy in 16 patients diagnosed with $S$. maltophilia bacteraemia

\begin{tabular}{|c|c|}
\hline $\begin{array}{l}\text { Median number of days of treatment with TMP/ } \\
\text { SMX (IQR) }\end{array}$ & $13(8-14.5)$ \\
\hline $\begin{array}{l}\text { Median daily dose of trimethoprim (in } \mathrm{mg} / \mathrm{kg} \text { ) at } \\
\text { the end of the treatment period (IQR) }\end{array}$ & $6.6(4.2-13.2)$ \\
\hline $\begin{array}{l}\text { Number of patients to whom TMP/SMX was being } \\
\text { administered at a lower than recommended high } \\
\text { dose }(<5 \mathrm{mg} \text { TMP/kg; TID) [1] at the start of the } \\
\text { treatment period (patients } 1,2,3,4,6,7,12,17 \text {, } \\
18,22 \text { and } 26 \text { in Table } 2)\end{array}$ & $11(69 \%)$ \\
\hline $\begin{array}{l}\text { Number of patients for whom a dose reduction was } \\
\text { required because of a reaction to the medication } \\
\text { (renal toxicity; patients } 2 \text { and } 13 \text { in Table 2) }\end{array}$ & $2(13 \%)$ \\
\hline $\begin{array}{l}\text { Number of patients for whom TMP/SMX was } \\
\text { changed to fluoroquinolones because of treatment } \\
\text { complications (i.e. delirium; patient } 10 \text { in } \\
\text { Table 2) }\end{array}$ & $1(6 \%)$ \\
\hline $\begin{array}{l}\text { Median percentage of the recommended dose }(5 \mathrm{mg} \\
\text { TMP } / \mathrm{kg} \text {; TID) that was adjusted to the weight and } \\
\text { renal function of the patient (IQR) }\end{array}$ & $\begin{array}{l}44.2 \% \\
\quad(33.1-70.5)\end{array}$ \\
\hline $\begin{array}{l}\text { Median percentage of normal dose }(5 \mathrm{mg} \mathrm{TMP} / \mathrm{kg} \text {; } \\
\text { BID) that was adjusted to the weight and renal } \\
\text { function of the patient (IQR) }\end{array}$ & $\begin{array}{l}66.3 \% \\
\quad(49.7-105.8)\end{array}$ \\
\hline
\end{tabular}

TMP/SMX trimethoprim-sulfamethoxazole, IQR interquartile range

against S. maltophilia in vitro clinically recovered and none of them died in the 30-day period following the onset of the infection. No differences in outcomes were observed with respect to the use of different TMP/SMX dosages.

\section{Discussion}

Various studies have reported a mortality rate for $S$. maltophilia infections of $15-29 \%$ and the mortality rate for bacteraemia was even higher, reaching up to $62 \%$ [4$7,10]$. However, in this study, we observed an excellent prognosis with clinical improvement and no 30-day mortality when adequate treatment with TMP/SMX and/or a fluoroquinolone was provided, even when the daily TMP dose was lower than $15 \mathrm{mg} / \mathrm{kg}$ [1]. The most striking finding of the current analysis was a zero mortality rate in adequately treated patients diagnosed with $S$. maltophilia bacteraemia. We identified four factors that might have contributed to these excellent outcomes for treatment.

First, the S. maltophilia isolates in this study were all susceptible to TMP/SMX in vitro. This is in agreement with an overall low rate of TMP/SMX resistance (3.7\%) for S. maltophilia in Switzerland (http://www.anresis.ch). This is in contrast to higher rates of TMP/SMX resistance reported in other European countries and in North America [11].

Second, the use of TMP/SMX in most of our patients very likely contributed to the positive outcomes in this study, given that TMP/SMX is known to be the most efficient antimicrobial for either monotherapy or combination therapy against susceptible $S$. maltophilia isolates $[1,2]$. Newer fluoroquinolones, minocycline or tigecycline might be future alternatives to combat emerging TMP/ SMX resistance; however, the selection of resistant $S$. maltophilia strains with the use of quinolones remains a concern [2]. The administration of TMP/SMX can be associated with adverse events such as neutropaenia, hepatopathy or decreased tubular secretion of creatinine and also with more uncommon severe skin diseases such as Stevens-Johnson syndrome or with central nervous system side effects [3]. However, the complication rate in this study was low. It is, therefore, noteworthy that the average dose of TMP used in the study was lower than the normally recommended dose of $15 \mathrm{mg} / \mathrm{kg}$ body weight per day. It is especially noteworthy in light of the low toxicity rate among these patients and the generally excellent outcomes. However, prospective, well-controlled and larger studies are required in order to confirm these retrospective findings on TMP/SMX dosages for treating $S$. maltophilia bacteraemia.

Third, the patients in the group whose antimicrobial therapy conformed with our definition of adequate treatment were somewhat younger $(p<0.001)$ and also required less time in the intensive care unit (ICU) than other patients in the study whose therapy did not conform to the definition of adequate treatment $(p=0.004)$, which indicates lower morbidity in the group.

Fourth, a central line was the focus identified in twothirds of the cases, which has been shown in earlier studies to be associated with a lower mortality rate $[5,6]$.

The limitations of the study are the rather small number of cases and the retrospective design of the study. The strengths of the study include the amount of information that was provided by the detailed work-ups of patients with S. maltophilia bacteraemia, in particular the information about therapeutic aspects and outcome in each case. In addition, the involvement of an infectious disease specialist in all but two cases provided specialised and detailed data about the cases that are still useful years after the events occurred.

In conclusion, S. maltophilia bacteraemia is a serious condition, but it appears to have a low mortality rate when central lines are removed as quickly as possible after the onset of infection and patients receive adequate treatment, preferably treatment with TMP/SMX, if the identified pathogen is shown to be susceptible to this antimicrobial agent in vitro.

Acknowledgments We would like to thank Sigrid Strom, Seattle, WA, for her excellent editing of the manuscript. This work was supported by the Stiftung Forschung Infektionskrankheiten, Basel, 
Switzerland (SFI 43/2013). The study sponsors had no involvement in the study design, in the collection, analysis and interpretation of data, in writing the manuscript or in the decision to submit the manuscript for publication.

Conflict of interest The authors declare that there are no conflicts of interest.

\section{References}

1. Looney WJ, Narita M, Mühlemann K. Stenotrophomonas maltophilia: an emerging opportunist human pathogen. Lancet Infect Dis. 2009;9:312-23.

2. Nicodemo AC, Paez JI. Antimicrobial therapy for Stenotrophomonas maltophilia infections. Eur J Clin Microbiol Infect Dis. 2007;26:229-37.

3. Nguyen AT, Gentry CA, Furrh RZ. A comparison of adverse drug reactions between high- and standard-dose trimethoprim-sulfamethoxazole in the ambulatory setting. Curr Drug Saf. 2013;8:114-9.

4. Yeshurun M, Gafter-Gvili A, Thaler M, Keller N, Nagler A, Shimoni A. Clinical characteristics of Stenotrophomonas maltophilia infection in hematopoietic stem cell transplantation recipients: a single center experience. Infection. 2010;38:211-5.

5. Garazi M, Singer C, Tai J, Ginocchio CC. Bloodstream infections caused by Stenotrophomonas maltophilia: a seven-year review. J Hosp Infect. 2012;81:114-8.
6. Muder RR, Harris AP, Muller S, Edmond M, Chow JW, Papadakis K, et al. Bacteremia due to Stenotrophomonas (Xanthomonas) maltophilia: a prospective, multicenter study of 91 episodes. Clin Infect Dis. 1996;22:508-12.

7. Senol E, DesJardin J, Stark PC, Barefoot L, Snydman DR. Attributable mortality of Stenotrophomonas maltophilia bacteremia. Clin Infect Dis. 2002;34:1653-6.

8. Horan TC, Andrus M, Dudeck MA. CDC/NHSN surveillance definition of health care-associated infection and criteria for specific types of infections in the acute care setting. Am J Infect Control. 2008;36:309-32.

9. Carroll KC, Cohen S, Nelson R, Campbell DM, Claridge JD, Garrison MW, et al. Comparison of various in vitro susceptibility methods for testing Stenotrophomonas maltophilia. Diagn Microbiol Infect Dis. 1998;32:229-35.

10. Fihman V, Le Monnier A, Corvec S, Jaureguy F, Tankovic J, Jacquier H, et al. Stenotrophomonas maltophilia - the most worrisome threat among unusual non-fermentative gram-negative bacilli from hospitalized patients: a prospective multicenter study. J Infect. 2012;64:391-8.

11. Gales AC, Jones RN, Forward KR, Liñares J, Sader HS, Verhoef J. Emerging importance of multidrug-resistant Acinetobacter species and Stenotrophomonas maltophilia as pathogens in seriously ill patients: geographic patterns, epidemiological features, and trends in the SENTRY antimicrobial surveillance program (1997-1999). Clin Infect Dis. 2001;32:S104-13. 